\title{
Membranous Positivity Present
}

National Cancer Institute

\section{Source}

National Cancer Institute. Membranous Positivity Present. NCI Thesaurus. Code C83178.

An immunophenotypic finding indicating positive membranous reactivity to a specific antibody. 